\title{
Establishment of Open Governance in Georgia: Challenges and Opportunities
}

\author{
${ }^{1}$ Genadi Iashvili, ${ }^{2}$ Giga Phartenadze, ${ }^{3}$ Irakli Manvelidze \\ ${ }^{1}$ Georgian Technical University, Georgia, ${ }^{2}$ Georgian Technical University, Georgia, ${ }^{3}$ Batumi Shota Rustaveli State \\ University, Georgia
}

\begin{abstract}
The development of the public administration information sector in Georgia has made it necessary to develop greater public sector openness, whereas in the era of information telecommunication technologies the development of open governance is a strategic commitment to promoting the economic well-being of a society, the formation of a democratic environment and stability. It enhances the country's macro and micro economic environment, national competitiveness, facilitates the necessary democratic change with rational actions, promotes improvement of public administration processes and encourages broadening of public transparency, efficiency and effectiveness. It is noteworthy to say that the Georgian government has declared development of open governance as a precondition and priority for strategic development, building of a democratic, free, legal state, economic and social advancement and development of human resources.

The process of open governance development has a significant impact on the functioning of the public administration system in Georgia. The analysis of the state legal normative and governance practices of modern Georgia allows us to conclude that the introduction of open governance technologies and values helps to reduce misunderstandings between the state an
\end{abstract}


society and to strike a balance. At the same time, the introduction of management openness tools enhances the trust between the state and society, including effective feedback.

The study of open governance as a new theory of governance and its practical context is a novelty in the Georgian scientific literature. Fundamental research in this field is still a novelty in Georgian reality. Our research in Georgian reality is distinguished by the novelty of the issue. At this stage of the study we are limited to conducting only theoretical research, which required the processing of information in both foreign and Georgian languages and defining the postulates of the new theory of open governance. In Georgian reality, open governance is seen as a new technical model of management, at the same time, for objective reasons, Georgian sources do not provide enough material to analyze the problem, accordingly, we used foreign sources and literature in the study. Therefore, the presented research is a novelty in terms of studying the theoretical and methodological aspects of public administration in Georgia.

Key words: Management, Governance, State, Society, Government 


\section{Introduction}

One of the key instruments to sustaining the sustainability and evolutionary development of social organizations in the age of globalization and information is the transition to a system of governance that is capable of responding quickly and effectively to continuous and everchanging internal and external challenges and threats. Therefore, at the modern stage, such a reform of public administration can be considered as successful which makes perfect certain governance functions and processes, as well as a qualitatively new system of interaction between the subject and the object of governance is being formed.

Open Governance is an international process coordinated by the Open Government Partnership. This is a joint initiative of the Presidents of the United States and Brazil, which they founded in 2011 as an initiative of eight countries. The initiative calls for greater transparency of governments and branches of government. The governments of the partnership countries undertake to be more open to citizens involve them in decision making and make government services accessible and comfortable. The degree of fulfillment of the commitments will determine the country's success within the framework of the "Open Government Partnership" [1]. Today the platform unites more than 60 countries. Georgia joined the platform in September 2011 [2]. The main goals of the Open Government Partnership are transparency, accountability and citizen involvement in government decision-making processes using new technologies and innovative methods [3].

\section{Methods}

The research strategy is based on the specifics of the selected research object and subject, goals and objectives. The purpose of the study is to analyze the current state of implementation of open governance in Georgia and identifying key postulates of the development strategy. Therefore, the objectives of the study were to describe a theoretically functional system of open governance as a new theory of governance in Georgia and identifying the characteristics of open government as a transparent governance system, which helped us identify problems in implementing open governance as a governance mechanism in Georgia. 
International conference on Research in MANAGEMENT

18-20 October, 2019

Budapest, Hungary

We used theoretical and empirical research methods to solve these problems. Among theoretical methods it should be noted systematic, structural-functional, institutional and

comparative analysis methods. Documentary analysis is an important method of empirical research. These methods have partially solved the problem of verifying the scientific information obtained. The use of different methods has enabled us to fully understand and analyze the theories of public administration. For example, using the systematic analysis method we came to understand the research object as a whole and to reveal different links in the conceptual context of the research object. In this respect, we have considered open governance at all levels of the system as a whole. Using the method of institutional analysis, we have dealt with the existing management institutions of the open government as a management institution; the use of the functional method has helped us to understand the function of open government bodies and their external and internal relationships. By comparative method we made comparative analysis of modern and traditional management strategies; a holistic analysis approach has helped us to identify trends in institutional unification of open government as a tool of communication with citizens. Thus, the method of researching the issue has enabled us to bring the problem to the theoretical and practical level.

The study covered both theoretical and practical issues related to open governance such as: justification of the need to move to a new paradigm of open governance in Georgia during the information society; assessing and measuring the quality of governance openness in Georgia; analysis of the problems of implementing transparency management mechanism in Georgia and revelation of potential benefits.

\section{Results and Discussion}

Georgian Government views openness, transparency, accountability and involvement of citizens in decision-making as fundamental values for democratic society and continues to adhere to the principles of Open Government Partnership (OGP) in public governance. Georgia was one of the first countries to join the OGP in 2011 and has implemented major reforms under the three action plans already implemented. Georgia became a member of the OGP Steering 
International conference on Research in MANAGEMENT

Committee in 2014 and in 2016 a co-chair state for the 2017-2018 term. As a co-chair country Georgia hosted the Fifth Global Summit of the OGP on July 17-19, 2018. The event brought together representatives from over 70 countries, hundreds of members of civil society,

international organizations, academia and the media. About 80 panels and sessions were held within the Summit [4].

For the transition to open government, it would be wise, at least for the Georgian authorities, to recommend to the Georgian government and local self-government bodies, to increase the efficiency of their functions and to address the objectives set out in the light of the principle of openness.

It should be noted that Georgia has civil plans for establishing open governance, in particular, the Open Government Georgia 2014-2015 Action Plan has been implemented to date [5], as well as Open Government Georgia Action Plan 2016-2017[6] and Open Government Georgia's 2018-2019 Action Plan [4]. Part of the ideas and norms contained therein are gradually implemented in practice, as evidenced by a number of normative legal acts, which was the basis for the realization of the principles of openness by the central authorities of the executive branch.

Along with the great leap in the use and development of information technologies in public administration, the Open Government Georgia's Civil Strategy contains serious basis for providing new forms and means of information to citizens on various issues of public life.

Since 1972, leading world experts and analysts have been conducting an annual comparative study based on a wide range of sources, including news, articles, scientific analysis, NGO reports and professional reports and then publish a report on political rights and civil liberties consisting of quantitative and qualitative assessments for 195 countries, which are rated in "Freedom in the World" [7]. It should be noted that the legal norms often do not actually equate to the results of the applicable law in this report. Monitoring of legislative norms and legal practices are held in order to calculate ratings. At the same time the emphasis is on the quality of enforcement. In addition, the report largely values the rights and freedoms of ordinary citizens and not the rights of state or non-governmental organizations. 
International conference on Research in MANAGEMENT

Georgia occupies an average position with 63 points in the 2019 "Freedom in the World" report [7]. In the framework of this study, we do not aim to analyze the results of the evaluation and its dynamics. In addition, we consider it necessary to distinguish from the over 100 indicators included in the summary index those reflecting the formation of a qualitatively new system of interaction between state authorities and civil society.

The "Freedom in the World" rating includes a number of key indicators that reflect the state's accountability to the public during the elections. Indicators are compiled in the form of questions where positive answers mean that the state has a strategy of moving towards openness and transparency as its own development vector [9].

On the basis of Open Government of Georgia Action Plans, publicly important projects have been developed in Georgia and implemented by government authorities to enhance interaction and communication with citizens. Among these it is important to indicate the direction of the development of electronic governance as a result of which there is an improvement in the provision of information tools that are directly linked to the openness and accessibility of socially important information.

The transition to a working e-government system that facilitates the secure and legally significant exchange of electronic documents between the state and citizens provides a steadily growing demand for citizens to receive public and important information for him. At the modern stage, citizens are keen to receive additional information on state that are useful to them and satisfy their interests. If the state is committed to conducting its activities openly, then the process of meeting additional information requirements will be prioritized by citizens, and may also bring in some new economic profits both for state and citizens (For example, open data on cadastral engineers when citizens need the services of a cadastral engineer, etc.).

Management of state registries (registries, accounting systems, databases, etc.) is one of the most common powers vested in the central authorities of the executive branch. Most of these registries include socially important information, which should be more or less accessible to citizens. However, it is often evidenced that the absence of a unified state policy on access to 
International conference on Research in MANAGEMENT

information, administration of which are vested with the authority of the executive there are a number of administrative barriers.

Authorities receive a great deal of information from citizens in the exercise of their powers (such as issuing licenses or other permits, accreditations, etc.), often, however, such information is related to the payment of various state duties by citizens. Then, at the expense of budgetary funds, government agencies set up complex information systems to process the information they receive (For example, licenses registries, accounting systems, etc.). Lastly, on

the basis of an application for public service and often as a result of the applicant's fees, the authorities provide citizens with information on the information resources available and at least for twice of the cost.

First of all, for the transition to open government, cardinal changes in the asymmetric distribution of state information are needed. The information available to everyone must be open except information which is restricted by law. This does not mean that any information in the registry should be open. Moreover, it should be emphasized that the disclosure of information also requires the financial authority to incur financial costs. We need to introduce statutory restrictions only on the closed part of the registry (In the form of personal data or other information protected by law or classified information) and only publicly available information should become open. At the same time, civil society needs to know what kind of information is at the disposal of state authorities and what information is a closed one.

Closed information available from special registries (registries, information systems, etc.), which by law may not be available to the public should be treated as a public service as required by the accounting system of the authorities. At this time it is necessary to precisely identify the specific categories of applicants, as required by law, who have the right to receive such information and have the right to request information that is not public.

A number of statutory acts oblige executive authorities to prepare a state report annually on the situation in their respective areas. For example, the sectoral ministries of Georgia prepare official reports, calculations, and conclusions on individual activities of ministries. Documents of 
International conference on Research in MANAGEMENT

this kind, like other reporting and analytical materials produced by government agencies that reflect aspects of the country's socio-economic and political-cultural development, must necessarily be publicly available, understandable and, most importantly, reusable (as well as must be opened in hard copy). Reporting and analytical materials should also be available for open criticism, the results of which should also be accessible to everyone.

In turn, the implementation of the information openness strategy of the authorities will stimulate IT innovation in the field and will create all conditions for equal competition and provision of information services.

Nowadays there is some kind of deviation from some state legislative norms from IT technologies. If not this, it would have contributed to more effective use of public administration. It has to be said, however, that there is an increasing demand on review of the impact of legislation on the actualization and improvement of norms regulating the participation of citizens in the drafting and decision-making processes of public authorities. It will also increase public control over the enforcement of judgments, especially through the use of IT tools.

Limited expansion of the means and forms of public engagement at all levels and processes of governance will help to reduce the efficiency of decision-making by the authorities, increasing the cost of additional negotiations making it unclear the responsibility of government officials for the outcome of decisions that lack the professional foundations of public administration.

While we have made some progress in the development of e-government in Georgia, it is time to talk about the need for the public to take the need for information satisfaction to a new level in principle. At the same time, it should be emphasized that the continuous and adapted provision of new information by the state to citizens is essential for the economic growth of society and the continuous social development.

Positive Trends in E-Government Creation - Providing e-services through state portals has a positive effect on citizens' trust in the activities of public authorities [10]. Proponents of the 
International conference on Research in MANAGEMENT

theory of public values believe that the introduction of information and communication technologies stimulates the development of the principles of cooperation and transparency and increases the opportunities for e-democracy in the state [11].

The implementation of projects implemented by the state in the field of e-government is considered as an important direction for the transition to open governance. Within the framework of these projects, electronic services introduced by the state, such as electronic public procurement, transparent data, electronic petitions, review and development of new norms, creation of electronic communications space between government officials and the public, developing and delivering information services to citizens, electronic reporting on agency activities and others are considered as an important starting point for the introduction of open

governance. All such projects are based on ensuring that a wide range of citizens have access to the Internet and are able to access state information systems and official portals.

The creation of an open governance system does not mean to abandon the further development of e-government technologies that have proven their effectiveness in practice. Egovernance can be seen as a facilitating mechanism for the development of open governance.

\section{Conclusions}

In the process of reforming the state governance in Georgia at the modern stage, which is unfortunately characterized by the lack of value-driven boundaries and the rapid penetration of Internet technologies into all aspects of public and private life, the transition to open governance allows us to mobilize state and civil society efforts so as to consolidate the conflicting interests of completely different interest groups through public policy.

Formation of a new model of open governance in Georgia is a gradual process, which faces difficult institutional problems. It primarily competes with the e-government model and seeks to make it one of the instrumental mechanisms for its implementation.

In fact, open governance in Georgia, as a new model of public administration, does not change the results of the previous stages of reform in public administration, but focuses on the 
International conference on Research in MANAGEMENT

technological improvement of the public governance process using the information society value system.

The process of establishing open governance in Georgia can be carried out in line with international practice. In this case, it will have an explicit emphasis on publicity, using specific tools and mechanisms already tested.

It should be borne in mind that the introduction of technological governance instruments does not guarantee that the balance between the state and society will be maintained and that an appropriate level of public control over the protection of legality will be achieved. At the same time, not one single principle of openness should be realized in relation to one or more of the functions of governance, but only interconnected and complex solutions allow us to ensure a consistent movement towards open governance. In such conditions, democratic values such as pluralism, freedom of speech, transparency, openness, access to information mean maximum openness of the activities of government and public organizations, as well as their

interconnectedness and mutual responsibility, which will allow citizens to express their views on any issue of state and public life.

\section{References}

[1] Official Website of the Ministry of Justice of Georgia, Open Government, Available: http://www.justice.gov.ge/Ministry/Index/347

[2] Open Government Forum in Georgia, Available: https://idfi.ge/ge/open-governmentpartnership

[3] Open Government as Georgia's Priority, Available: https://www.transparency.ge/ge/content/stub-543

[4] Open Government Georgia's 2018-2019 Action Plan, Available: http://procurement.gov.ge/getattachment/International-Cooperation/Action-Plans/(OGP)/OGP2018-2019-AP.pdf.aspx 
International conference on Research in MANAGEMENT

[5] Open Government Georgia 2014-2015 Action Plan, Available: http://www.justice.gov.ge/Multimedia\%2FFiles\%2FOGP\%2FUSA\%2FGov.\%20Decree\%20557 \%20-\%20FINAL.pdf

[6] Open Government Georgia 2016-2017 Action Plan, Available: http://www.justice.gov.ge/Ministry/Index/347

[7] Freedom In The World 2019, Available: https://freedomhouse.org/report/freedomworld/freedom-world-2019

[8] Methodology, Available: https://freedomhouse.org/report/methodology-freedomworld-2019

[9] Eric W.Welch, Charles C. Hinnant and M. Jae Moon (2005) Linking Citizen Satisfaction with E-Government and Trust in government Journal of Public Administration Research and Theory. N15 (3). P. 371-391

[10] Luna-Reyes L., Chun S., Pardo T. et al. Open government and e-government: Democratic challenges from a public value perspective. Information Polity: Th e International Journal Of Government \& Democracy In Th e Information Age [serial online]. March 2012. 17(2):83-97. Available at: Business Source Complete, Ipswich, MA. (Accessed February 6, 2014) 